\title{
Bírói hatalmi ág az Alaptörvényben - a bírói függetlenség néhány aspektusáról
}

\section{BALOGH ZSOLT ${ }^{1}$}

Az Alaptörvény biróságokat érintő része az elmúlt tíz év alatt többször módosult. A tanulmány nem érint minden változást, így nem tárgyai az elemzésnek a közigazgatási bíráskodással kapcsolatos kérdések. E munkában a bírói függetlenség szempontját elötérbe helyezve mutatunk be néhány olyan - egykor közérdeklödésre számot tartott - ügyet, amellyel összefüggésben az Alaptörvény is módosult. Így foglalkozunk - a túlzott munkateher csökkentése és a jogviták észszerü határidőn belül történő elbírálása céljából létrehozott - ügyáthelyezés lehetöségével, továbbá a bírók korai nyugdijazásával, valamint a bíróságok központi igazgatására létrehozott alkotmányos konstrukcióval. A tanulmány második része a bírói függetlenség egyes kérdéseit az itélkező bíró szemszögéböl elemzi. Nem titkolt célunk gyakorlati érveket felhozni a mellett, hogy az igazságszolgáltatás jogállami müködését az elmúlt tíz évben nem érte csorba.

Kulcsszavak: Alaptörvény, igazságszolgáltatás, bírói hatalmi ág, bírói függetlenség, bíróságok központi igazgatása, bíróságok tekintélyének védelme

\section{A Branch of Judicial Power in the Basic Law - On Some Aspects of Judicial Independence}

The part of the Constitution concerning courts has been changed several times in the last ten years. This paper does not concern all amendments, therefore, issues related to administrative justice are not discussed. In this study - bringing to the fore the viewpoint of judicial independence-we discuss some cases of public interest, in connection with which the Constitution has been amended. We are dealing with the possibility of relocation of cases, early retirement of judges, and the constitutional system for central administration of the courts. The second part of the study analyses some aspects of judicial independence from the perspective of the judge. We are presenting practical arguments with the aim of demonstrating that the rule of law prevails in jurisdiction.

1 Kúriai bíró, tanácselnök; c. egyetemi docens, Pázmány Péter Katolikus Egyetem Jogés Államtudományi Kar. 
Keywords: Constitution, jurisdiction, branch of judicial power, judicial independence, central administration of the courts, maintaining the authority and impartiality of the judiciary

\section{Bevezetö}

Az Alkotmánybíróság a bírói hatalmi ág alkotmányos státuszát bemutató első határozatában úgy fogalmazott, hogy amíg a törvényhozó és végrehajtó hatalom folyamatosan megújul, addig e dinamizmus mellett az igazságszolgáltató hatalom állandó. ${ }^{2} \mathrm{Az}$ Alaptörvény hatálybalépését követő tíz évben - kicsit szarkasztikusan fogalmazva - épp ellentétes tendenciát látunk, mint amit az Alkotmánybíróság egykor leírt. A törvényhozó és végrehajtó hatalom politikai következetessége (állandósága) mellett a bírói hatalmi ágat számos változás érte. A dinamizmus és nem az állandóság volt a jellemző az igazságszolgáltatásra az elmúlt tíz évben. Bírói nyugdíjazás, közigazgatási és munkaügyi bíróságok létrehozása, majd megszüntetése. Annak az ígérete, hogy maga az igazságszolgáltatás is két ágra szakad: a rendes és a közigazgatási bíróságokra, majd ez mégsem következett be, de a munkaügyi ítélkezés szétvált, ${ }^{3}$ az elsőfokú közigazgatási bíróságokból nyolc jött létre törvényszéki szinten. De említhetnénk legutóbbról az úgynevezett jogegységi panasz intézményének létrehozását, ami a jogegységesítésben hoz majd újdonságot. Azt mondhatjuk, hogy az egyébként természetét tekintve konzervatív, a változásokra nehezen reagáló bírói hatalmi ágat jelentős változások, átalakulások érték az Alaptörvény hatálybalépése óta. A számok is tükrözik ezt: az Alaptörvény kilenc módosításából négy is érintette a bíróságokat, ${ }^{4}$ míg az Országgyülésre két technikai módosítás vonatkozott, ${ }^{5}$ a Kormány múködését pedig alaptörvény-módosítás egyáltalán nem érintette.

Mindezek mellett az ítélkezés továbbra is színvonalas maradt, az ügyek befejezésének ideje pedig jóval rövidebb, mint az európai átlag. ${ }^{6}$ A változások egy jogállamban természetesnek tekinthetők, ha a bírói függetlenséget nem éri csorba. Ezt

2 38/1993. (VI. 11.) AB határozat III/2.

3 A társadalombiztosítási perek és a közszolgálati jogviták közigazgatási bírósági hatáskörbe kerültek, míg az egyéb munkaügyi perek a polgári bíráskodás körébe.

4 Az Alaptörvény negyedik és ötödik módosítása, valamint a hetedik és nyolcadik módosítása.

5 Az Alaptörvény negyedik és nyolcadik módosítása.

6 Álljon itt példaként: 2010-es évre vonatkozó elsőfokú polgári peres ügyek befejezésének ideje 1. Ausztria (129 nap); 2. Magyarország (160 nap); 3. Lengyelország (180 nap); 4. Németország (184 nap); 5. Franciaország (279 nap); 6. Szlovénia (431 nap); 7. Horvátország (462 nap). 2014-es adatok, hogy mennyi időn belül lehet egy szerződéses követelést adott országban érvényesíteni: 1. Németország (394 nap); 2. Magyarország (395 nap); 3. Ausztria (397 nap); 4. Egyesült Királyság (437 nap); 5. Horvátország (572 nap); 6. Lengyelország (685 nap); 7. Szlovénia (1270 nap). Lásd részletesen: Czoboly Gergely A polgári perek elhúzódása. In Jakab András - Gajduschek György (szerk.): A magyar jogrendszer állapota. Budapest, Társadalomtudományi Kutatóközpont Jogtudományi Intézet, 2016. 758-776. 
pedig komolyan vehető kritika az Alaptörvény hatálybalépése óta nem érte, a bírói függetlenség mint az igazságszolgáltatás mủködésének alapja Magyarországon kétségbevonhatatlan tény. A bírák függetlenek, és csak a törvénynek vannak alárendelve, ítélkezési tevékenységükben nem utasíthatók - mondja az Alaptörvény 26. cikke, már hatálybalépése óta, de hasonlóan fogalmazott az Alkotmány is. ${ }^{7}$ A hatalommegosztás rendszerében a bírói függetlenség a bírói hatalmi ág immanens sajátossága, amely elsősorban politikai, de minden más (például gazdasági) befolyástól mentes ítélkezési tevékenységet jelent.

Az alábbiakban a bírói hatalmi ág alapjogi összefüggéseiből két kérdést érintünk. Egyrészt az Alaptörvény-módosítást is „megjárt” egyes ügyeket mutatjuk be azzal a nem titkolt szándékkal, hogy a mögöttük rejlő problémák - így visszanézve - nem is biztos, hogy olyan súlyúak voltak, mint az azokat kísérő reakciók. Másfelől a bírói függetlenséghez kapcsolódó pár kérdést járunk körbe. A perspektíva az alulnézet, a tanulmány a gyakorlatra fókuszál, azaz az egyes jogintézményeket a kevésbé érintett, elemzett vagy hangsúlyozott kérdések szempontjából mutatjuk be.

Alaptörvény-módosítással járt a közigazgatási bíráskodással kapcsolatos hetedik ${ }^{8}$ és nyolcadik módosítás is. E tanulmány a közigazgatási bíráskodással nem foglalkozik, mert a bírói függetlenség kérdéseit eseteken keresztül kívánjuk megragadni, az önálló közigazgatási bíráskodás pedig végül nem is jött létre. A közigazgatási bíráskodás kérdése egyébként tárgyában is eltérő, önálló tanulmányt igényel.

\section{Alaptörvény-módosítások egyes jogintézményekhez kapcsolódva}

\section{1. Ügyáthelyezés}

Alaptörvényi relevanciájú az Országos Bírósági Hivatal (OBH) elnökének ügyáthelyezési lehetősége. A bíróságok szervezetéről és igazgatásáról megalkotott akkor még új törvény (Bszi.) ${ }^{9}$ lehetővé tette, hogy az OBH elnöke az ügy elbírálására az illetékes bíróság helyett kivételesen más, azonos hatáskörủ bíróságot jelöljön ki, ha az ügy vagy a bíróságra az adott időszakban érkezett ügyek meghatározott csoportjának elbírálása a bíróság rendkívüli és aránytalan munkaterhe miatt észszerủ időn belül másként nem biztosítható (és a kijelölés nem jár a kijelölt bíróság aránytalan megterhelésével). E rendelkezés alapján 2012-ben 42 ügyet helyezett át az OBH elnöke, ezek nagyobb része gazdasági per volt, és csak kisebb része büntetőügy. Az áthelyezett ügyek között volt néhány, nagy jelentőségű, politikailag érzékeny ügy is. Az ügyek nagy részében

7 Az Alkotmány 50. \$ (3) bekezdése értelmében: „A bírák függetlenek és csak a törvénynek vannak alárendelve. A bírák nem lehetnek tagjai pártnak és politikai tevékenységet nem folytathatnak." A politikai tevékenység tilalmát tartalmazza az Alaptörvény 26. cikkének folytatása, ami új az Alaptörvényben, hogy megfogalmazza a bírák ítélkezési tevékenységben történő utasításának tilalmát is.

8 Lásd pl. Patyi András: A magyar közigazgatási bíráskodás elmélete és története. A magyar közigazgatás és közigazgatási jog általános tanai VIII. kötet. Budapest, Dialóg Campus, 2019. 321. 
a felek az áthelyezésnek örültek, mert hamarabb született döntés. A közérdeklődés természetesen a politikailag érzékenyebb ügyeket követte. Az OBH elnökének ezt a jogosítványát számos támadás érte. Bevezetését követő fél év múlva törvénymódosítás jogorvoslatot biztosított az OBH elnökének döntése ellen a Kúriához, de ennek ellenére mind egyes belföldi, mind egyes külföldi fórumok elfogadhatatlannak tartották ezt a jogosítványt, többek között a bírói függetlenségre, a törvényes bíróhoz való jog sérelmére hivatkoztak.

Az Alaptörvény negyedik módosítása 2013. április 1-jével az ügyáthelyezést alaptörvényi szabállyá tette. Az Alaptörvény 27. cikk (4) bekezdése értelmében: „Az észszerü határidőn belüli bírói döntéshez való alapjog érvényesülése és a bíróságok kiegyensúlyozott ügyterhelése érdekében sarkalatos törvényben meghatározottak szerint az Országos Bírósági Hivatal elnöke sarkalatos törvényben meghatározott ügyek tárgyalására az általános illetékességű bíróságtól eltérő, azonos hatáskörü bíróságot jelölhet ki." Részben a Velencei Bizottság jelentése nyomán az Alaptörvény ötödik módosítása 2013. október 1-jétól hatályon kívül helyezte az Alaptörvény e szabályát. Az Alkotmánybíróság ezt követően hozta meg a 36/2013. (XII. 5.) AB határozatát, amely a Bszi.-nek a 2012. január 1. napjától 2012. július 16. napjáig hatályban volt ügyáthelyezésről szóló rendelkezéseiről megállapította, hogy azok alaptörvényellenesek voltak, és ugyanakkor nemzetközi szerződésbe is ütköztek. 2012. július 16-át követően az $\mathrm{OBH}$ elnöke ügyáthelyezésről meghozott döntése ellen biztosítottá vált a bírósági felülvizsgálat, a bírósági felülvizsgálatot a Kúria végezte, ezért állapította meg az Alkotmánybíróság, hogy az alkotmányellenesség csak eddig állt fenn. Az Alkotmánybíróság szerint a tisztességes eljáráshoz való jogon belül a törvényes bíróhoz való jogot sérti, hogy sarkalatos törvényben foglalt garanciák nélkül működött az ügyáthelyezés.

Az Alaptörvény ötödik módosítása, a Bszi. vonatkozó szabályainak hatályon kívül helyezése (és az alkotmánybírósági határozat) nyomán az ügyáthelyezés jogintézménye megszűnt a magyar jogban, mégpedig úgy, hogy az áthelyezett ügyek további jogi sorsát illetően sem az alkotmánybírósági határozat nem szólt semmit, sem pedig a jogalkotó nem rendelkezett, ami a későbbiekben problémákat okozott.

A 36/2013. (XII. 5.) AB határozat tiszteletben tartása mellett meg kell jegyeznünk, hogy az ügyáthelyezés esetén nem arról volt szó, hogy már bíróra kiosztott ügyet helyeztek át más illetékességű bírósághoz. Ezekben az esetekben arról volt szó, hogyha a kiemelt jelentőségủ nagy munkaigényű, bonyolult ügyekből egy bíróságon többszörösen sok volt, mint másutt, akkor a bíróság elnöke, még mielőtt kiosztotta volna, kérte az OBH elnökét, hogy az ügyek észszerü határidőn belül való befejezése érdekében azonos hatáskörü bírósághoz tegye át. Az ok, hogy ezekben az esetekben egy éven belül még az első tárgyalást sem tudta volna kitűzni a bíróság. Az OBH elnöke a Bszi., a 3/2012. (II. 20.) OBHE ajánlás, majd az Országos Bírói Tanács (OBT) által meghatározott elvek alapján - ha egyetértett a törvényszék elnökével - az ügyet áttette. Hivatalból nem járhatott el. Ezek a belső szabályozásban megfogalmazott elvek kizárólag az ügyteher figyelembevételét írták elő (az OBH elnöke bekérte az adato- 
kat, a vonatkozó ügytípusra vonatkozó leterheltség alapján sorrendet állapított meg, s e szerint tette át). Meglehet nem sarkalatos törvényben fogalmazódtak meg az elvek, de a Bszi. a jogintézménnyel való élés kivételessége körében megfogalmazta azt, hogy csak akkor van lehetőség az áttételre, ha „az ügy vagy a bíróságra az adott időszakban érkezett ügyek meghatározott csoportjának elbírálása a bíróság rendkívüli és aránytalan munkaterhe miatt ésszerű időn belül másként nem biztosítható és a kijelölés nem jár a kijelölt bíróság aránytalan megterhelésével”. Véleményünk, hogy a jogintézmény alkotmányos életben tartásához ennyi törvényi garancia is elég lett volna a mellett, hogy az áthelyezésről való döntés ellen már jogorvoslati lehetőség is rendelkezésre állt a Kúriához. Még egyszer hangsúlyozandó, hogy nem az ügyek bíráktól való elvételéről volt szó, és hangsúlyozandó az is, hogy a jogintézmény átmeneti jellegéből adódóan addig maradt volna hatályban, míg az illetékességi szabályok módosítása révén a törvény el nem rendezi az arányosabb ügymegosztást. Az OBH elnöke döntése feletti bírói kontrollhoz a Bszi. szabályai elég támpontot adtak. Az ügyáthelyezés önálló eljárási rendben zajlott, ezért semmilyen befolyással nem járt az alapügy mikénti eldöntésére.

Az ügyben az sem kapott nyilvánosságot, hogy a jogintézményt eredetileg nem az Alaptörvény, illetve az új Bszi. hozta létre, hanem a bíróságok szervezetéről és igazgatásáról szóló 1997. évi LXVI. törvényt (a régi Bszi.) módosító 2010. évi CLXXXIII. törvény (Bszim.) vezette be. A Bszim. értelmében az eljárás az OIT elnökének indítványára indult, a döntést pedig a Legfelsőbb Bíróság - jogorvoslat kizárásával - hozta meg. Az eljáró bíróság kijelölése jogintézményével a korábbi bírósági vezetés is élt, alkotmányossági problémát akkor nem vetett fel. ${ }^{10}$

\subsection{Bírói nyugdijjkorhatár}

Ahogy a bíróságok szervezetét és müködését érintő változások, úgy a bírák jogállására vonatkozó átalakítások is kritika tárgyát képezték. Sokáig uralta a közéletet a bírói nyugdíjkorhatár 62 évre csökkentése.

Az Alaptörvény 26. cikk (2) bekezdése szerint a Kúria elnöke - későbbi módosítást követően ide került az OBH elnöke is - kivételével a bíró szolgálati jogviszonya az általános öregségi nyugdíjkorhatár betöltéséig állhat fenn. Az Alaptörvény átmeneti rendelkezései - az általános nyugdíjkorhatár fogalmának fenntartása mellett - határidőket is tartalmaztak: két hullámban, 2012. június 30-ával és 2012. december 31-ével szűntek volna meg a bírói szolgálati viszonyok. A konkrét rendelkezéseket a bírák jogállásáról és javadalmazásáról szóló törvény (Bjt.) ${ }^{11}$ tartalmazta, de nyilvánvaló, hogy a bírák Bjt. szerinti szolgálati viszonyának a nyugdíjkorhatár elérése miatti

10 Balogh-Békesi Nóra: A bírói hatalmi ág az Alaptörvény rendszerében. Iustum Aequum Salutare, 12. (2016), 4. 9-19.

11 2011. évi CLXII. törvény a bírák jogállásáról és javadalmazásáról. 
megszüntetése az Alaptörvény és az Átmeneti rendelkezések ${ }^{12}$ által támogatott volt. Hozzá kell mindehhez tenni, hogy az Átmeneti rendelkezések alkotmányos súlyát az Alaptörvény első módosítása az Alaptörvény rangjára emelte. ${ }^{13}$

Az Alkotmánybíróság a 33/2012. (VII. 17.) AB határozatában fogalmi pontatlanságot talált: az Alaptörvény és az Átmeneti rendelkezések ,általános öregségi nyugdíjkorhatárról” szólnak, míg a Bjt. „rá irányadó öregségi nyugdíjkorhatár”-ról rendelkezik. A határozat értelmében a jogrendszer nem ismeri az általános öregségi nyugdíjkorhatár fogalmát, így az tulajdonképpen alkalmazhatatlan. Az Alkotmánybíróság szerint: „Az általános korhatárt [...] úgy szabad értelmezni, hogy ennek eredménye ne vezethessen a bírói függetlenség lényeges elemei sérelmére."

A bírói függetlenséget illetően a döntés indokolása a történeti alkotmány fogalmának értelmezésével indít, azaz annak meghatározásával, hogy mit is jelent az a szabály, amely szerint az Alaptörvényt a történeti alkotmányunk vívmányaival összhangban kell értelmezni. ${ }^{14}$ Az Alkotmánybíróság szerint felelőssége ebben az új helyzetben rendkívüli, mondhatni történelmi: a konkrét ügyek vizsgálatakor kötelezően be kell emelnie kritikai horizontjába a jogi intézménytörténet releváns forrásait. A határozat arra jut, hogy a bírói függetlenség történelmi kiteljesedése a bírói elmozdíthatatlanság rögzítésével indult, a bírói hatalom gyakorlásáról szóló egykori törvények is a 70. életévben határozták meg a felső korhatárt. A bírói függetlenség mint modern alkotmányos garancia ennek a folyománya. A határozat szerint: „A bírói függetlenséggel összefüggésben megállapítható, hogy a bírói szolgálati jogviszonyok stabilitásának biztosítása olyan, az Alaptörvényből folyó követelmény, amely más jogviszonyokhoz képest is többlet garanciákat igényel. A bírák Alaptörvény által garantált elmozdíthatatlansága egyebek között olyan személyes garancia, amely a bírák döntési autonómiájának biztosítéka, mivel kizárja annak lehetőségét, hogy a törvényeknek és lelkiismeretének megfelelő ítélete miatt közvetett, a szolgálati jogviszonyával összefüggő retorzió érje. A »független bíró«-hoz való jog ugyanakkor az eljárás alanyai számára az Alaptörvény XXVIII. cikk (1) bekezdésében biztosított jog is. A bírák elmozdíthatatlansága a független, pártatlan bírósághoz való jog garanciája is egyben. A jogalkotónak erre tekintettel a bírói hivatás gyakorlásának felső korhatárát oly módon kell meghatároznia, hogy az egyértelmű és előre kiszámítható legyen" - érvel a határozat. ${ }^{15}$

Az alkotmánybírósági döntés a Bjt. rendelkezéseit ex tunc hatállyal, a törvény kihirdetése napjára visszamenőleg semmisítette meg, azonban nem tartalmazott előírást arra nézve, hogy a visszaható hatályú megsemmisítésének mi a hatása a különböző

12 Az Átmeneti rendelkezések nagy részét az Alkotmánybíróság ezen év végén semmisítette meg a 45/2012. (XII. 29.) AB határozatával.

13 Magyarország Alaptörvényének első módosítása (2012. június 18.) 1. cikk (1) bekezdése szerint Az Alaptörvény Záró rendelkezések része a következő 5. ponttal egészül ki: „5. A 3. pont szerint elfogadott Magyarország Alaptörvényének átmeneti rendelkezései (2011. december 31.) az Alaptörvény részét képezi."

14 Lásd Alaptörvény R. cikk (3) bekezdés.

15 A döntés részletes elemzésére lásd: Balogh-Békesi Nóra: „Marbury felmentése” Alkotmánybírósági hatáskör-elemzés a bírói korhatár ügyön keresztül. Jogtudományi Közlöny, 67. (2012), 10. 420-427. 
jogviszonyokra, sőt még az eljárás alapját képező, alkotmányjogi panaszokat illetően sem tartalmazott rendelkezést. Így volt olyan bíró, aki közvetlenül a köztársasági elnökhöz fordult, és kérte a kinevezését, volt olyan, aki az OBH elnökétől kérte, hogy terjessze elő kinevezésre, volt olyan, aki munkajogi pert indított (ehhez kapcsolódva született olyan ítélet, amely hatályon kívül helyezte a köztársasági elnök felmentéséről szóló döntését), s végül volt olyan bíró is, aki az alkotmánybírósági határozatot követően másnap egyszerüen „csak” bement dolgozni.

Mindenesetre azt mondhatjuk, hogy a bírói nyugdíjjal kapcsolatos történések felkavarták a közéletet. Ugyanakkor az alkotmánybírósági eljárás majd annak következményei az Alaptörvény keretei között megnyugtatóan tudták rendezni a problémát. Ami az Alaptörvény kritikája, az egyben a dicsérete is.

Végül ebben az esetben is úgy tudunk összegezni, mint az ügyáthelyezésnél: a bírói kar fiatalítása, rugalmasabbá tétele legitim cél ugyan, azonban a megvalósítás módja nem állta ki az alkotmányosság (az idő) próbáját. ${ }^{16}$

\section{3. $O B H-O B T$}

Az Alaptörvény hatálybalépésével a 25. cikk (5) bekezdése akként rendelkezett, hogy a bírói önkormányzati szervek közreműködnek a bíróságok igazgatásában. Az Alaptörvény eredetileg nem írta le a bíróságok központi igazgatásának modelljét, nem szólt az Országos Bírósági Hivatalról, sem az elnökéről, de nem tartalmazott szabályt az Országos Bírói Tanácsról sem. E szabályokat az Alaptörvénnyel párhuzamosan hatályba lépett, a bíróságok szervezetéről és működéséről szóló törvény tartalmazta. ${ }^{17}$ Az Alaptörvényből egy követelmény következett, a bírói önkormányzati szervek közreműködnek a bíróságok igazgatásában, ${ }^{18}$ de ebből bármelyik központi igazgatási modell: akár a külső, akár a belső, de akár a vegyes modell is következhetett volna. ${ }^{19}$ A törvényhozó a bíróságok szervezetéről és működéséről szóló törvényben a belső önigazgatási modellt választotta (illetve olyat, ami ehhez hasonlít leginkább). A Velencei Bizottságnak a bírósági reformmal kapcsolatos egyik kifogása az Országos Bírósági Hivatal elnökének jogosítványaival ${ }^{20}$ és az ez által megvalósult igazgatási modellel függtek össze. Sokan hatalomkoncentrációt, mások a bírói önigazgatás megszünését látták abban, hogy a bíróságok igazgatását az $\mathrm{OBH}$ elnöke látja el, $\mathrm{s}$ a modellre úgy tekintettek, hogy nem történt más, mint az Országos Igazságszolgáltatási Tanácsot mint testületet kicserélték az Országos Bírósági Hivatal elnökére. De azt is mondhatnánk, hogy egy önigazgatási modellel állunk szemben, amelyben a parlamenti 2/3-os

16 Balogh-Békesi (2016) i. m.

17 Lásd a 2011. évi CLXI. törvény VI. és VII. fejezetét.

18 A bírói hatalmi ág közremủködését a bíróságok irányításában eredetileg a 38/1993. (VI. 11.) AB határozat írta le alkotmányos követelményként. Az Alaptörvény e szabálya lényegében ehhez igazította az alkotmányos környezetet.

19 Lásd részletesebben: Balogh-Békesi (2016) i. m.

20 Lásd: Európa Tanács Velencei Bizottsága 2012. márciusban elfogadott CDL(2012) 001. számú, 2012. októberében elfogadott CDL-AD (2012) 20. számú véleményét. 
választás miatt erős legitimációval rendelkező $\mathrm{OBH}$-elnök maga is bíró, tevékenysége fölött a 15 bíróból álló OBT felügyeleti jogot kapott. Külföldi és hazai kritikák alapján az igazgatási modell annyiban módosult, hogy az OBT felügyeleti jogosítványait erősítették (pl. bírói pályázat elbírálásánál az OBT egyetértési joga szükséges, ha a pályázati rangsortól el szeretne térni az OBH elnöke). ${ }^{21}$

Jelentős változás, hogy az Alaptörvény 2013. szeptember 26-ai ötödik módosítása az Alaptörvénybe emelte a bíróságok igazgatásának konkrét modelljét. A 25. cikk kiegészült azzal a szabállyal, hogy „[a] bíróságok igazgatásának központi feladatait az Országos Bírósági Hivatal elnöke végzi. Az Országos Bírói Tanács felügyeli a bíróságok központi igazgatását. Az Országos Bírói Tanács és más bírói önkormányzati szervek közreműködnek a bíróságok igazgatásában." Az OBT mint szervezet és feladata alkotmányos szintre emelkedett, a modell az Alaptörvényt tiszteletben tartó és jogalkalmazó bírák számára adott.

Az OBH elnökéhez telepített, OBT által kontrollált modell törvényi szabályait vizsgálta az Alkotmánybíróság a 3/2013. (VI. 17.) AB határozatában. Az Alkotmánybíróság szerint az OBT hatásköreire is figyelemmel nem vezethető le annak szükségessége a bírói függetlenség alkotmányos elvéből, hogy a bíróságok központi igazgatása felett felügyeletet gyakorló testületnek feltétlenül lennie kell más hatalmi ágaktól származó, szavazati joggal rendelkező tagnak is. A Velencei Bizottság azonban a második jelentése szerint továbbra is úgy vélekedett, hogy az OBT összetételének „pluralisztikusnak" kell lennie, és nem csak bírákból kellene állnia. Fontos, hogy ezt a pluralisztikus összetételt nem csupán nem bíró személyek vendégként való meghívásán keresztül érjék el, hanem utóbbiak teljes jogú, szavazati joggal rendelkező tagok legyenek. ${ }^{22}$

Az OBH elnökének és az OBT-nek a viszonya eredetileg kiegyensúlyozott volt. A modell - azaz az OBT ellenőrzési funkciója - megmutatta más arcát az OBT-tagok választását (kicserélődését) követően. Amíg az $\mathrm{OBH}$ elnökét kilenc évre választja az Országgyűlés, addig az OBT tagjainak megbízatása hat évre szól. Ez az időbeli eltérés eredményezte az új választást és a korábbitól eltérő tagságú OBT létrehozását. Az új összetételü OBT tevékenysége az OBH elnökének ellenőrzésében - mondjuk így - igen progresszív volt, számos anomália keletkezett, amely az igazságszolgáltató hatalmi ág külső megítélésére is hatott.

Újabb konfliktust idézett elő egyes OBT-tagok lemondása. A bíróságok szervezetéről és igazgatásáról szóló törvény szerint az OBT bíró tagjává egy ítélőtáblai, öt törvényszéki, hét járásbírósági és egy közigazgatási és munkaügyi bírósági bírót választ. ${ }^{23}$ A probléma abból adódott, hogy olyan bíró mondott le, aki egyedül képviselte az adott szintet - mert kérdésként merült fel, hogy ilyenkor az OBT egésze működésképtelen, vagy az a szabály érvényesül, hogy az OBT akkor határozatképes, ha

21 Lásd a bírák jogállásáról és javadalmazásáról szóló 2011. évi CLXII. törvény (Bjt.) 18. \$ (4)-(5) bekezdését.

22 Lásd a CDL-AD (2012) 20. számú vélemény 34. pontját.

23 2011. évi CLXI. törvény 91. $\$(1)$ bekezdés. 
az ülésén tagjainak legalább kétharmada jelen van. ${ }^{24} \mathrm{~A}$ törvény erre az estre nem tartalmazott rendelkezést. Az egyik értelmezés szerint a törvény a határozatképességhez nem füzi azt, hogy minden választási kategóriákból legalább egy-egy bírónak jelen kell lenni, illetve más módon sem utal az összetételre, a határozatképes kétharmad összetételére. A törvény az OBT összetétele vonatkozásában egyfajta arányosságot kíván biztosítani a bírósági szinteket képviselő bírák számának meghatározásával. A szabályozás azt tiltja, hogy a törvényben tételesen meghatározott felső határt bírósági szintenként és összességében is átlépjék (jellemzően, ha a bíró bírósági szintre történő beosztása megváltozik), azonban azt nem zárja ki, hogy ha az adott bírósági szint kiüresedik, akkor az OBT ne müködhessen tovább. Ezzel ellentétes vélemény szerint a szintek szerinti képviseletnek garanciális jelentősége van, ha az adott bírósági szint egyáltalán nem képviselteti magát, sérül az a törvény által létrehozni kívánt megoldás, amely szerint minden bírósági szintnek legyen legalább egy bírája az OBTben. Mindez az OBT müködőképességét érinti, ha egy szint nem képviselteti magát, az OBT múködésképtelen. Jelenleg a póttagválasztások eredményeként a fenti müködési zavar (kérdése) megoldottnak látszik.

Az OBH elnök - OBT kettősén alapuló modell létrehozása óta több arcát is megmutatta. Ez az igazgatási modell finomítással, bizonyos jogosítványok tisztításával, áthelyezésével, hosszú távon mégis csak működtethető központi igazgatási konstrukciónak tűnik, bár mind a külső (az igazságügyi igazgatáson alapuló), mind a vegyes rendszer (a bírói önigazgatás elemeit is magán viselő, de külső tagokból is álló modell) ismert és elfogadható megoldás. A jelenlegi rendszer Alaptörvényben rögzített volta azonban annak elfogadását nem teheti vitássá.

\section{A bírói függetlenség egyes „gyakorlatias” kérdései}

3.1. Az Alaptörvény 26. cikk (1) bekezdése akként foglalja össze a bírói függetlenséget, hogy „[a] bírák függetlenek, és csak a törvénynek vannak alárendelve, ítélkezési tevékenységükben nem utasíthatóak. A bírákat tisztségükből csak sarkalatos törvényben meghatározott okból és eljárás keretében lehet elmozdítani. A bírák nem lehetnek tagjai pártnak, és nem folytathatnak politikai tevékenységet."

Nyilvánvaló, hogy a bírói függetlenség nem önmagáért való függetlenség. Ahogy megfogalmazást nyert: „[A] függetlenségnek van két áthághatatlan korlátja: a bírák nem dönthetnek önkényesen és soha nem változtathatják meg a jogszabályokat, ideértve azt is, hogy nem ronthatják le a jogszabályok észszerủ tartalmának érvényesülését. [...] A függetlenség ugyanis nem a bíróságokért önmagukért van, hanem a törvényhozó hatalom által hozott törvények érvényesítése (objektív oldal) és a törvényekben biztosított alanyi jogok megvédése (szubjektív oldal) érdekében. A füg-

$24 \quad 105 . \$(3)$ bekezdés. 
getlenség tehát alkotmányos célhoz kapcsolódik, nemcsak valamitől, hanem valami érdekében független az igazságszolgáltatás." ${ }^{25}$

Hozzá kell ehhez tenni, hogy a bírói függetlenség nem a bíró személyes előjoga, ${ }^{26}$ hanem a bírói hatalmi ág jogállami mủködésének garanciája. A bíró a törvény alá van rendelve, a törvény irányítja és programozza a bírói tevékenység tartalmát. A törvény alá rendeltség alapja a jogállamiság, a jog minden állami cselekvés mértéke. A bíró az államot képviseli, ezért egyben az egyéni alapjogok érvényesíthetőségének kötelezettje, aki az Alaptörvény I. cikk alapján védi az alapjogokat is. Felelösséggel terhes függetlenség ez.

A bírói függetlenség megfogalmazódik úgy is, mint a bírói hatalmi ág államszervezeti függetlensége. Ez az intézményi függetlenség, amibe nemcsak az tartozik bele, hogy a bírák tevékenységének függetlennek kell maradni más hatalmi ág befolyásolásától, hanem az is, hogy függetlennek kell maradni a nem állami szféra befolyásától is. A bírói függetlenség megjelenik úgy is, mint a bíró ítélkezési tevékenységének függetlensége a bíróságok igazgatásától. A bírói függetlenség a bírósági szervezeten belül is érvényesül. $\mathrm{S}$ a bírói függetlenség újabb dimenziója a bíró személyes meggyőződése védelmében, de egyben az ítélkezéssel szemben fennálló személyes felelősségében ölt testet. Ide vehetjük a jogértelmezési függetlenséget és felelősséget. ${ }^{27} \mathrm{~S}$ mindehhez hozzátartozik, hogy „minden szinten” nemcsak pártatlannak kell lenni, hanem annak is kell látszani. ${ }^{28}$

3.2. Az Alaptörvény a bírói függetlenség körében a politikai tevékenység tilalmának kiemelésével a politikamentes jogalkalmazás követelményét első helyre teszi. De hiába pártatlan a bíró, hiába hoz szakmai szempontból makulátlan döntést, nem egyszer azt tapasztaljuk, hogy az elfogultság vádja éri, vagy az a vád, hogy nem a társadalom elvárása szerint döntött. Hogyan lehetséges ez? A továbbiakban ezt a kérdést érintjük.

3.2.1. A bíró törvény alá rendelt. A jogi szabályozásban vannak olyan normák, amelyeket aktuális politikai törekvések szültek, s vannak olyan normák, amelyek politikai szempontból közömbösek. Ez természetes jelenség, minden jogrendszerben így van. Megfigyelhető azonban az a tendencia, hogy minél inkább politika által motivált az adott alkalmazandó jog(szabály), az azon alapuló döntés pártatlansága is annál inkább kétségbe vonódik, holott a bíró nem volt elfogult, az adott normát csupán alkalmazta. A túlpolitizált jogi normák és az azok között bukdácsoló bírák kapcso-

25 Varga Zs. András: Tíz gondolat a jogegységről és a precedenshatásról. Magyar Jog, 67. (2020), 2. 81-87.

26 A bírói függetlenség és az azzal összefüggő alanyi jogok kapcsolata külön elemzést igényelne. A független bíróhoz való jog felfogható úgy, hogy a felek számára biztosított alanyi jog, de magának a bírónak ez nem „joga”. A bírói függetlenség a bíró oldaláról alanyi jogként nem fogható fel, ha „jogiasítani” kellene legfeljebb „szervi” jogról beszélhetnénk (de ez is messzire vezetne, ha pl. a jogérvényesítésre gondolunk).

27 A jogértelmezési függetlenséget illetően lásd Varga Zs. András idézett művét. Varga Zs. (2020) i. m.

28 A bírói függetlenséget sokan, több szempontból elemezték, értékelték. Ez az írás nem vállalkozik sem a történeti előzmények, sem a különböző nézetek, finom eltérések bemutatására. De arra igen, hogy a bírói függetlenség megkérdőjelezésének néhány aspektusát felvillantsa. 
lata nem új keletű, az ilyen normák (ügyek) alkalmazásának kivédésre a történelem során számos megoldás született. ${ }^{29}$ Azonban a formális jogállam követelménye azt közvetíti, hogy a demokratikus legitimációval rendelkező jogalkotó által, a jogalkotási eljárás garanciális szabályainak betartásával megalkotott jogszabályokat a bírónak alkalmazni kell, akkor is, ha a norma egyébként politikailag motivált, azaz olyan kérdéseket szabályoz, amelyben a politikai szereplők éles szembenállása tapasztalható. Ugyanakkor a bíró nem teljesen eszköztelen, ha ítélkező tevékenysége során a norma alkalmazhatóságát kétségbe vonja. A bíró fordulhat az Alkotmánybírósághoz, kérheti az alkalmazandó norma alkotmányossági vizsgálatát. Önkormányzati norma törvényellenessége esetén kérheti a Kúria Önkormányzati tanácsának eljárását. A bírói kezdeményezés lehetősége a bírói függetlenség vívmánya ${ }^{30}$ kifejezi, hogy a bíró ugyan a törvénynek van alárendelve, de csak az alkotmánnyal (Alaptörvénnyel) öszszhangban lévő törvénynek. ${ }^{31}$ Azonban annak a jogszabálynak az alkalmazása, amely kiállta az alkotmányosság próbáját nem vonható kétségbe, függetlenül a szabályozást ért egyéb kritikáktól. Továbbá amennyiben az alkalmazandó norma az Európai Unió jogának értelmezése körében bizonytalan, a bíró előzetes döntéshozatali eljárást kezdeményezhet az Európai Unió bíróságánál. Tehát a fentiek alapján számos lehetősége van a bírónak az alkalmazandó jogszabály tekintetében.

3.2.2. A bírói ítélkezés kétségbe vonódhat akkor is, ha olyan jogvitában kell döntenie a bírónak, amelyre vonatkozóan a jogi szabályozás hiányos. ${ }^{32}$ A bíró ebben az esetben van a legnehezebb helyzetben. A szabályosan előterjesztett kérelem alapján az eljárási szabályok értelmében határozni kell akkor is, ha döntésének jogszabályi behatárolása homályos, a jogszabályi keretek nem egzaktak. Ilyenkor „kisegítő” elvek bevonásával lehet egzaktabbá tenni a döntést: egykor például a szokásjog, ${ }^{33}$ később a korábbi hasonló döntések láncolatának segítségül hívásával, vagy értelmezési klauzulák, az észszerűség követelményének bevonásával lehet megnyugtató(bb) döntést

29 Lásd pl. Észak-Amerikában a politikai kérdések doktrínáját (political question doctrine), amelynek értelmében a bíró csupán abban az esetben jár el, ha a jogvitában illetékes, kérik a döntését, és az adott eset elbírálható (justicable) és nem politikai ügy. Azonban, hogy mi a politikai ügy, azt a bíróág dönti el - ezáltal azonban a primátus a bíróságok felé csúszik át, ami nem kevésbé veszélytelen.

30 Lásd: Alaptörvény 24. cikk (2) bekezdés b) pont, Abtv. 24. cikk (2) bekezdése - megjegyzendő, hogy garanciális okokból indokolható lenne az Alkotmánybíróságról szóló 2011. évi CLI. törvény (Abtv.) 24. $\mathbb{S}(2)$ bekezdése teljes szövegének - a bírói kezdeményezés lényege leírásának - is az alaptörvényi szintre emelése, mint ahogy azt pl. a litván alkotmány 110. cikk (2) bekezdése tartalmazza.

31 Európai alkotmányozási tendenciákat figyelembe véve a szöveg úgy lenne pontos, hogy „a bírák függetlenek, csak az Alaptörvénynek és a törvénynek vannak alárendelve" - lásd pl. az Észt Alkotmány 146. cikkét vagy a görög alkotmány 87 . cikk (2) bekezdését.

32 Meg kell jegyezni, hogy sem a korábbi, az Alkotmánybíróságról szóló 1989. évi XXXII. törvény, sem a most hatályos Abtv. alapján a bíró - az alkotmánybírósági értelmezés szerint - az előtte lévő eljárás felfüggesztése mellett nem kezdeményezheti mulasztásban megnyilvánuló alkotmányellenesség megállapítását az Alkotmánybíróság előtt. Ez a gyakorlat álláspontunk szerin megérett az újragondolásra.

33 Lásd pl. a törvénypótló szokásjogról: Szabó István: Az ősi alkotmány. In Csink Lóránt - Schanda Balázs (szerk.): A magyar közjog alapintézményei. Budapest, Pázmány Press, 2020. 83-122. 
hozni. Ebben az esetben a bíró akkor jár el helyesen, ha a szokásánál alaposabban indokol, s a jogi érveket lehetőleg olyan indokokkal támasztja alá, amelyek nyilvánvalóak, széles körben ismertek.

3.2.3. Szinte mindig előkerül a pártatlanság kérdése, ha a bíróságnak olyan ügyben kell dönteni, amelyben politikai szereplő közvetlenül érintett, vagy direkt politikai kérdésről van szó, vagy olyan ügyről, amelyre vonatkozóan a jogi szabályozás nem tükrözi a társadalmi elvárást (vagy azzal épp ellentétes). ${ }^{34}$ De ezek az ügyek is hozzátartoznak az ítélkezés mindennapjaihoz, a döntésnek olyannak kell lennie, hogy szakmai szempontból kifogástalan legyen, se eljárási kérdésekben sem az anyagi jogi szabályok alkalmazásában ne vonódjon (semmilyen vonatkozásban) kétségbe annak szakmai helyessége.

A bírói függetlenség kétségbe vonása kapcsán gyakran hangoztatott érv, hogy hiába dönt a bíróság több ezer ügyben pártatlanul, ha a politikai érdeklődésre számon tartott egy-két ügyben kétségbe vonható döntés születik. A bírónak olyan döntést kell hozni, hogy az ilyen jellegü vád fel se merülhessen. A gyakorlatban előfordulnak olyan eseteket is, amikor a nehéz helyzetek kombinálódnak: nincs megfelelő szabályozás, de egyben a közérdeklődés, politikai érdeklődés középpontjában áll az ügy.

3.2.4. Felvethető egy szervezeti kérdés is. „A bírói függetlenség az ítélkezésre vonatkozik, a további, státuszbeli és szervezeti garanciák is a független ítélkezéshez szükségesek" - hangsúlyozta az Alkotmánybíróság. ${ }^{35}$ A bírói függetlenség mindenre kiterjedő függetlenség, ideértve a bírósági igazgatásban betöltött szerepet is. Ha nem így lenne, a bírói tevékenység nem független része támadási felületet teremtene a függetlenség egészére. Elvárás tehát, hogy a bíróra a nem ítélkezési feladatok átruházása ne teremtsen semmilyen lehetőséget az ítélkezés külső befolyásolására, továbbá az igazgatási eszközök és azok alkalmazása ne teremtsenek alkalmat még a pártatlanság látszatának a kétségbevonására sem.

3.2.5. S végül néhány szót érdemes szólni az ítélkezés függetlensége és a sajtó kapcsolatáról. A sajtó befolyásoló szerepe a hatalommegosztás rendszerében már 1947-ben felmerült Bibó István akadémiai székfoglalójában. Nem államhatalmi ág, de a sajtó olyan tényező, amelynek „véleményformáló hatása egyszerre döntő tényezője a tömegműveltség emelkedésének és ugyanakkor a hatalomkoncentráció minden eddigi mértéket meghaladó növekedésének. ${ }^{36}$ Mára az írott és elektronikus sajtó, illetve az azóta belépő internet véleményformáló hatása több százszorosa a Bibó által feltételezett egykori szerepének. Nézzük a mai szerepeket az igazságszolgáltatás szemszögéből.

Az, hogy a bíró nem nyilatkozhat az eljárásról, nem magyarázhatja döntését, inkább a bírói függetlenséget védi. Önkorlátozást igényel azonban a bírótól, ha nyilvánvalóan félreértik a döntését, szándékkal félremagyarázzák, vagy a leginkább előfor-

34 A közvélemény ítélkezésre gyakorolt nyomásával összefüggésben lásd: Varga Zs. András: A jog többrétegüsége. Budapest, Károli Gáspár Református Egyetem Állam- és Jogtudományi Kar, 2020. 88.

35 Lásd: 38/1993. (VI. 11.) AB határozat.

36 Lásd: Bibó István: Államhatalmak elválasztása egykor és most. Vigília, 45. (1980), 8. 533-546. 
duló eset, hogy a sajtó - a döntést kommentáló - nem közli a döntést meghatározó olyan jogi tényt vagy tényállási körülményt (csak a kritikát), ami egyébként észszerü magyarázatot ad, hogy miért úgy határozott a bíróság, ahogy. A bíróságok által esetenként kiadott közlemény - mondjuk így az igazságszolgáltatás védekezése - sok esetekben nem alkalmas eszköz a véleményformáló nagy médiumok állításainak cáfolatára. Más eszköz pedig nincs.

Az ítélkezés és a sajtó kapcsolatát tekintve különbséget kell tenni a döntés meghozatala előtti és a döntés utáni reakciók között. Az ítélet kihirdetése előtt a nyilvános tudósításnak és véleményközlésnek annyira visszafogottnak kell lenni, hogy a bíróra a függetlenséget fenyegető semmilyen nyomást ne fejtsen ki. Ezt követeli meg a bíróság befolyásolásának tilalma. A bírósági ítéletek ellenőrzése csak utólagos lehet s ez csak a jogorvoslati eljárásban képzelhető el - a hatalommegosztás elve tiltja a nem bírósági típusú szerv által végzett állami ellenőrzést. Az ítélet után a politikailag motivált tartalmi kritikák és politikai reakciók természetesek, de az nem torkollhat a bíró elleni személyeskedésbe. A nem tudományos sajtó és más médiumok elemzéseinek, a bírósági döntések vitatásának határt szabhat a bíróságok tekintélyének fenntartásához füződő érdek.

A sajtó és a bíróságok funkcióinak összevetése igazi alapjogi mérlegelési helyzetet eredményez. A sajtó alkotmányos feladata a közvélemény tájékoztatása. A sajtószabadság, a véleménynyilvánítási szabadság igen magas értéktartalmú jogok. Ugyanakkor a kommunikációs alapjogok sem korlátlanok, nemzetközi egyezményben elismert korlátja, hogy a joggyakorlás nem járhat a bíróság tekintélyének sérelmével. ${ }^{37} \mathrm{E}$ korlát betartása egyébként (hosszú távon) azoknak is érdeke, akik a bíróságokat, az ítélkezést érintő sajtóhíreket fogalmazzák, a sajtókiadványokat szerkesztik.

\section{Utószó}

Az igazságszolgáltató hatalmi ág államszervezeti helyének, funkcióinak, alapelveinek elméleti megközelítése fontos, mert ezáltal látunk rá az egészre. Fontos a nemzetközi összehasonlítás is, mert ezáltal látjuk a standardoknak való megfelelést, ötleteket nyerhetünk. Ugyanakkor számos olyan írás és vélemény fogalmazódik meg a bírói hatalmi ágról, számos olyan sommás állítás lát napvilágot, amely az igazságszolgáltatás mindennapjainak ismerete alapján árnyaltabb kellene hogy legyen.

Nehéz mủfaj alkotmányos szabályokat „alulnézetből” vizsgálni, különösen úgy, hogy a konklúzió valahogy mégis felérjen az alkotmány szintjére. A tanulmány valami ilyesmire vállalkozott.

Az Alaptörvény tíz éve van hatályban. A bírói hatalmi ágra vonatkozó alaptörvényi szabályok más helyeken is módosultak, mint amit e tanulmány érintett, ezen szabályokról is lehetne hasonló elemzést készíteni. ${ }^{38} \mathrm{E}$ tanulmány az egyes kérdések

37 Lásd az Emberi Jogok Európai Egyezményének (kihirdette az 1989. évi XXXII. törvény) 10. cikk 2. pontját.

38 Lásd a közigazgatási bíráskodással kapcsolatos hetedik, majd nyolcadik módosítást. 
kapcsán arra próbált rávilágítani, hogy a magyar igazságszolgáltatási rendszer működése a jogállami kritériumoknak megfelel, a korrekciós mechanizmusok - akár a jogalkotásra, akár az alkotmánybírósági eljárásokra, akár a jogértelmezésre gondolunk - működése alkalmas az esetleges diszfunkciók kiküszöbölésére.

\section{Irodalomjegyzék}

Balogh-Békesi Nóra: „Marbury felmentése”. Alkotmánybírósági hatáskör-elemzés a bírói korhatár ügyön keresztül. Jogtudományi Közlöny, 67. (2012), 10. 420-427.

Balogh-Békesi Nóra: A bírói hatalmi ág az Alaptörvény rendszerében. Iustum Aequum Salutare, 12. (2016), 4. 9-19.

Bibó István: Államhatalmak elválasztása egykor és most. Vigília, 45. (1980), 8. 533-546.

Czoboly Gergely: A polgári perek elhúzódása. In Jakab András - Gajduschek György (szerk.): A magyar jogrendszer állapota. Budapest, Társadalomtudományi Kutatóközpont Jogtudományi Intézet, 2016. 758-776. Online: https://jog.tk.hu/uploads/files/28_Czoboly_Gergely_perek.pdf

Patyi András: A magyar közigazgatási biráskodás elmélete és története. A magyar közigazgatás és közigazgatási jog általános tanai VIII. kötet. Budapest, Dialóg Campus, 2019.

Szabó István: Az ősi alkotmány. In Csink Lóránt - Schanda Balázs (szerk.): A magyar közjog alapintézményei. Budapest, Pázmány Press, 2020. 83-122.

Varga Zs. András: A jog többrétegüsége. Budapest, Károli Gáspár Református Egyetem Államés Jogtudományi Kar, 2020.

Varga Zs. András: Tíz gondolat a jogegységről és a precedenshatásról. Magyar Jog, 67. (2020), 2. 81-87. 